\title{
Eco-physiological response of two marine bivalves to acute exposition to commercial Bt-based pesticide
}

\author{
B. Manachini ${ }^{\mathrm{a}}$, V. Arizza ${ }^{\mathrm{a}}$, A. Rinaldi ${ }^{\mathrm{b}}$, V. Montalto $^{\mathrm{b}}$, G. Sarà ${ }^{\mathrm{b}, *}$ \\ ${ }^{a}$ Dipartimento di Biologia ambientale e Biodiversità, Università degli Studi di Palermo, Italy \\ ${ }^{\mathrm{b}}$ Dipartimento di Scienze della Terra e del Mare (DiSTeM), Università degli Studi di, Viale delle Scienze Ed. 16, 90128 Palermo, Italy
}

\section{A R T I C L E I N F O}

\section{Article history:}

Received 24 July 2012

Received in revised form

17 October 2012

Accepted 21 October 2012

\section{Keywords:}

Bacillus thuringiensis

Mytilaster minimus

Brachidontes pharaonis

Biological pollution

Biopesticides

Alien species

Agricultural coastal areas

\begin{abstract}
A B S T R A C T
Microbial products based on the entomopathogenic bacterium Bacillus thuringiensis (Bt) are among the most common biopesticides used worldwide to suppress insect pests in forests, horticulture and agricultural crops. Some of the effects of commercial Bt have been recorded for terrestrial and freshwater non-target organisms but little research is available on marine fauna. Nevertheless, due to the contiguity of agro-ecosystems and coastal habitats, marine fauna may be highly influenced by this control method. We studied the effect of a commercial Bt product on the physiological and ecological responses and the energy budget of two of the most frequent marine intertidal bivalves in the Mediterranean, the native Mytilaster minimus and the invasive Brachidontes pharaonis. To test the effects experimentally, we simulated the worst scenarios possible using the average dose applied to fields and a hypothetical accumulation dose. The results showed the feeding rates of both species were affected detrimentally by the different experimental conditions; higher concentrations led to higher respiration rates, however neither species showed any significant difference in excretion rates. The biopesticide had a significant effect on the energy budget, the values decreasing with doses. In addition, it led to high mortality for the worst treatments and, in both species, induced significantly higher cardiac activity than in the controls. These results indicate a measurable effect of Bt commercial products on marine organisms, and great attention should be paid to biopesticides composed by entomopathogenic bacteria and addictive compounds. In addition, the results highlight the urgent need to study not only the effects of anthropogenic pressures on target organisms but also to extend our view to other ecosystems not expected to be influenced. Gaining data at the organismal level should help increase the sustainability of pest control and reduce the consequences of side-effects.
\end{abstract}

(c) 2012 Elsevier Ltd. All rights reserved.

\section{Introduction}

The World Health Organization (WHO), the Food and Agriculture Organization (FAO) and other International Organizations are now calling for the development of environmentally sustainable systems that are less reliant on chemical pesticides as the primary management tools for pest control (FAO, 2010; Manachini, 2012).

In recent years, significant progress has been made in the development of biocontrol agents for the suppression of pests (e.g., insects, nematodes, molluscs), weeds and diseases impacting a wide range of forest, horticultural and agricultural crops (Laengle and Strasser, 2010; Manachini, 2012). Among biocontrol tools, microbial pesticides are generally regarded as posing lower risks

\footnotetext{
* Corresponding author.

E-mail address: gianluca.sara@unipa.it (G. Sarà).
}

to human health and the environment than chemical pesticides (OECD, 2007). Microbial pesticides are based on the entomopathogenic bacterium Bacillus thuringiensis (Bt), and are used worldwide for the control of lepidopterans and coleopterans (Manachini et al., 2011), and against aquatic larvae dipteran pests (Laengle and Strasser, 2010).

However bacteria and fungi used in biological control have, under certain conditions, the potential to act as opportunistic pathogens, infecting species not normally susceptible to these organisms (Laengle and Strasser, 2010). In fact, there is some evidence that also microbial agents can also infect other diseasecausing living organisms.

Non-target organisms present in agro-ecosystems and nearby areas, including coastal areas, can also be exposed to Bt in several ways including, for example, through feeding, transfer through the food chain, or by direct contact. Thus, the assessment of procedures for potential Bt impact on non-target marine organisms should be addressed in the context of biodiversity conservation. Many studies 
have investigated the potential effects of Bt toxins expressed in genetically modified plants and Bt commercial products mainly on non-target terrestrial fauna (Boisvert and Boisvert, 2000; Pouline et al., 2010) while there is little data on effects of marine organisms (Cervino et al., 2006; Eder and Schönbrunner, 2010). Some authors (Boisvert and Boisvert, 2000; Eder and Schönbrunner, 2010) have proposed the idea that accidental overspray or runoff containing commercial Bt could contribute to unexplained diseases in coral reef invertebrates. In addition, a possible effect of the endotoxin-producing Bacillus spp. was suspected in corals, sponges (Negri et al., 2009) and the marine worm Nereis (Hediste) diversicolor (Fourcy et al., 2002). Duchet et al. (2010) suggested a possible delayed effect of Bt-treatment in mesocosm on growth of Daphnia magna. Nevertheless no statistical significant correlation was found between Bt concentration and the mortality or longevity of shrimps (Eder and Schönbrunner, 2010).

$\mathrm{Bt}$ has also been isolated from marine habitats (Yin-Jjuan et al., 2008 ) and it is known that, in seawater, less than $10 \%$ of Bt (var. kurstaki) cells survived for 40 days after inoculation. Nevertheless, the activity of the viable spores, parasporal bodies and endotoxin in aquatic and more specifically marine habitats has not yet been definitively assessed. Only incomplete and contradictory data are available about the Bacillus spp. persistence in seawater (Menon and de Mestral, 1985; Surgeoner and Farkas, 1990; Tilquin et al., 2008; Van Cuyk et al., 2011).

While about $80 \%$ of the Earth's biodiversity is found in marine environments, the effect of pesticides on marine organisms remains relatively neglected (Callow and Willingham, 1996). Moreover, biomarkers commonly used to assess the impact on nontarget marine organisms are not fully appropriate to explain potential direct and indirect effects. Thus further investigations are pressing (Fourcy et al., 2002), and reliable models for this task could be limpets, winkles, mussels, crabs and fishes (Clynick et al., 2009; Dondero et al., 2011; Gagnaire et al., 2006) living in supratidal and intertidal habitats (where the terrestrial meets the marine realm; Sarà et al., 2012b). Due to their proximity, these habitats are particularly exposed and vulnerable to active substances coming from adjacent terrestrial habitats. Here, we have chosen two bivalve species as experimental models to study the effect of $\mathrm{Bt}$ in a marine environment. Bivalves are among the most important ecosystem engineers in aquatic habitats (Gutierrez et al., 2003). Their role in ecosystems is particularly attractive, and they can be used as tools to study global ecological processes and to assess the effects of natural and anthropogenic stress in marine ecosystems (Sarà et al., 2011, 2012a). Indeed, marine bivalves are ubiquitous sessile animals able to play a key-role in modifying and structuring worldwide intertidal/subtidal habitats (sensu Bayne, 2004; Gutierrez et al., 2003; Jones et al., 1997; Manganaro et al., 2009; Sousa et al., 2009).

We focus on the effect of a biological insecticide used for Mediterranean crops on physiological responses of two intertidal Mytilids, the Lessepsian Brachidontes pharaonis (Fischer, 1870) and the autochthonous Mytilaster minimus (Poli, 1759). As no data are available on the susceptibility of these non-target organisms and data on exposure and concentration to Bt in seawater are scant and contrasting, we considered the two worst scenarios possible, using two high concentrations of commercial Bt. Thus, under laboratory mesocosmal conditions we measured, in both species, i) feeding rates, as expressed by clearance and ingestion rates, ii) oxygen consumption and excretion rates, iii) assimilation and absorption rates, iv) energy available for growth and reproduction (i.e., Scope for Growth, SFG - Widdows and Staff, 2006) and, lastly, heart beat rate, a reliable measure of stress successfully adopted in recent studies with other marine invertebrates (Dong and Williams, 2011; Halldórsson et al., 2007).

\section{Material and methods}

\subsection{Study area, sampling and experimental set-up}

Adults of $B$. pharaonis (mean total length $=2.0 \pm 0.5 \mathrm{~cm}$ ) and $M$. minimus (mean total length $=1.5 \pm 0.2 \mathrm{~cm}$ ) were collected by hand from two different intertidal areas on June 16 and 17, 2010: B. pharaonis from the Stagnone di Marsala Lagoon (Western Sicily, Southern Tyrrhenian; $37^{\circ} 52^{\prime} \mathrm{N}-12^{\circ} 28^{\prime} \mathrm{E}$ ) and M. minimus from Altavilla Milicia, close to Palermo (Western Sicily, Southern Tyrrhenian; $38^{\circ} 3^{\prime} \mathrm{N}-13^{\circ} 33^{\prime} \mathrm{E}$ ). Once collected, the specimens were brought back to the Laboratory of Experimental Ecology and Behaviour (Palermo, Italy) and were acclimated at standard laboratory conditions $\left(20 \pm 1{ }^{\circ} \mathrm{C}\right.$ and $37 \pm 1 \%$ ) in large 400-L tanks and fed with a monoalgal culture of Isochrysis galbana (ad libitum; Sarà et al., 2008). According to the common experimental procedures (Ezgeta-Balic et al., 2011; Sarà et al., 2008; Widdows and Staff, 2006) previously adopted with success in studying the bioenergetics of bivalves, the animals of both species were kept under acclimation conditions for two weeks. At the end of the acclimation period, we randomly collect 240 animals of each species; they were divided into six groups of 40 specimens and transplanted in six 10-L aquaria. Thus, we had 6 aquaria containing 40 specimens each ( $n=6 \times 40$, i.e., 240 ) of the two species, ready to be inoculated with Bt as described below. The inoculum used was prepared from a commercially available insecticide based on $B$. thuringiensis var. kurstaki H-3A, 3b EG 2424 (hereafter called Bt). The commercial product was applied as a suspension concentrate formulation containing $71.2 \mathrm{~g}$ of active product per litre (Bt as spores and crystal toxins). The treatment rate was $3.5 \mathrm{~L} / \mathrm{ha}$, which would be the mean presumed recommended rate for field applications (field dose, FD). A second dose was chosen to simulate a possible concentration and accumulation effect (accumulation dose, AD). Thus the concentrations applied to mesocosms were 45 and $90 \mu \mathrm{L} \mathrm{L}^{-1}$, respectively (AD and FD corresponding to $1.51 \times 10^{5}$ and $3.2 \times 10^{5} \mathrm{CFU} \mathrm{ml}{ }^{-1}$, respectively). Accordingly, we inoculated 2 aquaria with field dose - FD, 2 tanks with accumulation dose - AD and two aquaria were not treated with Bt and thus considered as control (here after called CTRL). This was performed for both species; the experiment consisted in measuring eco-physiological rates after $24 \mathrm{~h}$ of Bt exposure according to the following classical procedures.

\subsection{Physiological measurements}

After $24 \mathrm{~h}$ from treatment with different concentrations of Bt, as described above, we measured the following eco-physiological rates: clearance rate, respiration rate, food absorption efficiency and excretion rate using procedures described by Widdows and Staff (2006) and successfully applied by Sarà et al. (2008) and Ezgeta-Balic et al. (2011). In addition, heart beat rate in each bivalve species was measured by following procedures employed by Depledge and Anderson (1990), Halldórsson et al. (2007) and Sarà and De Pirro (2011). To measure the eco-physiological responses of $B$. pharaonis and M. minimus, we used eight individuals $(n=8)$ for each species collected from each 10 -L aquarium where they were treated with Bt. Clearance rates were individually measured in a closed system by placing one individual each in a beaker containing $1 \mathrm{~L}$ of filtered thermo-regulated seawater $\left(20^{\circ} \mathrm{C}\right)$. The beakers were positioned on heated stirring base plates that ensured constant temperature and kept the water mixed and oxygenated throughout the experimental sessions. After a period of $20 \mathrm{~min}$, as the bivalves started to filter, algal cells (I. galbana) were added to each beaker at an initial concentration of 25,000 cells $\mathrm{ml}^{-1}$. Twenty $\mathrm{ml}$ aliquots were sampled from every beaker at $30 \mathrm{~min}$ intervals over a period of $2 \mathrm{~h}$. The decline in I. galbana cell concentration was 
monitored using a Coulter Counter (Beckman Coulter ${ }^{\odot}$ Model Z2). Two control beakers, without B. pharaonis and M. minimus, showed no significant decline in cell concentration over the entire experimental period.

Clearance rate $(\mathrm{CR})$ was calculated using the following equation:

$\mathrm{CR}\left(\mathrm{l} \mathrm{h}^{-1}\right)=1 \mathrm{~L}\left(\log _{\mathrm{e}} \mathrm{C}_{1}-\log _{\mathrm{e}} \mathrm{C}_{2}\right) /$ time interval $(\mathrm{h})$

where $C_{1}$ and $C_{2}$ were the cell concentrations at the beginning and end of each time increment (i.e., every $30 \mathrm{~min}$ ). Clearance rates were used to calculate ingestion rates (IR), i.e., the amount of ingested food per hour (IR, mg food $\left.\mathrm{l} \mathrm{h}^{-1}\right)\left(\mathrm{IR}=\mathrm{CR} \times \mathrm{mg}_{\text {Algae }} \mathrm{l}^{-1}\right)$.

Respiration rate (RR) was determined by placing new individual bivalves ( 4 for each aquarium) in glass respirometers $(0.5 \mathrm{~L}$ and $0.25 \mathrm{~L}$ for $B$. pharaonis and M. minimus, respectively) containing filtered air-saturated seawater. The respirometer was sealed and the decline in oxygen concentration was measured using a Strathkelvin electrode (Model 282). Respiration rate was then calculated according to the following equation:

$\operatorname{RR}\left(\mu \mathrm{mol} \mathrm{O}_{2} \mathrm{~h}^{-1}\right)=\left[C_{t 0}-C_{t 1}\right] \times\left(V_{\mathrm{r}}\right) \times 60 /\left(t_{1}-t_{0}\right)$

where $C_{t 0}$ is the oxygen concentration at the beginning, $C_{t 1}$ the oxygen concentration at the end of the measurement and $V_{\mathrm{r}}$ is the volume of water in the glass respirometer.

Another type of experiment was planned to estimate food absorption efficiency (AE). Animals from every Bt treatment were fed for $24 \mathrm{~h}$ with the concentration of algal cells (I. galbana; 25,000 cells $\mathrm{ml}^{-1}$ ) and once the feeding was stopped they were maintained overnight in beakers with $1 \mathrm{~L}$ of filtered $(0.45 \mu \mathrm{m} \mathrm{GF} / \mathrm{F})$ seawater. At the end of this period, faeces were collected and $\mathrm{AE}$ was estimated by comparing the proportion of organic matter in the algal cells and mussel faeces, according to the Conover equation (1966):

$\mathrm{AE}=(F-E) /[(1-E) F]$

where $F$ is a relationship between the dry weight and the ash-free dry weight of algal food and $E$ is a relationship between the dry weight and the ash-free dry weight of faecal pellets. Algal food and faecal pellets were collected on GF/C filters (washed, burned to ashes, and pre-weighted). The filters were dried at $90{ }^{\circ} \mathrm{C}$ and weighed before burning them to ashes in a furnace at $450^{\circ} \mathrm{C}$ for $4 \mathrm{~h}$ and then measuring the weight again. Excretion rate (ER) was calculated according to the Catalano method (1987).

After physiological measurements, the bivalve tissues were removed from their shells and both dried at $90{ }^{\circ} \mathrm{C}$ to obtain tissue and shell dry weight.

The individual clearance rates $\left(\mathrm{L} \mathrm{h}^{-1}\right)$, oxygen consumption rates $\left(\mu\right.$ moles $\mathrm{O}_{2} \mathrm{~h}^{-1}$ ) and excretion rates $\left(\mu\right.$ moles $\mathrm{NH}_{4} \mathrm{~h}^{-1}$ ) were converted to mass specific rates for a 'standard mussel' of $1 \mathrm{~g}$ total dry weight using the weight exponent for each species. In order to calculate the energy budget and scope for growth (SFG), each physiological rate was then converted to energy equivalents $\left(\mathrm{Jh}^{-1} \mathrm{~g}^{-1}\right)$. SFG was calculated using the next equation:

$P=A-(R+E)$

where $P$ is energy available for growth and reproduction, $A$ is energy absorbed through food, $R$ represents energy lost by respiration and $E$ is energy lost by excretion. From this it follows that the scope for growth represents the difference between the energy absorbed from the food (food consumption $\times$ absorption efficiency) and the energy loss via metabolic energy expenditure.
As part of RR measurement, heart beat rate (HBR, beat $\mathrm{s}^{-1}$ ) was measured in single individuals using a phototransistor sensor (Sarà and De Pirro, 2011). We used six animals per species, per aquarium and per treatment. Each sensor was glued on the shell of the animal at the umbonal back position, and the signal read from the phototransistor was filtered and amplified by a speciallyconstructed electronic circuit and displayed by a digital oscilloscope (PicoScope 2203).

The last experiment was planned to measure mortality compared with the control group - after 24 and $48 \mathrm{~h}$ of exposure at the different Bt doses. In carrying out the experiment, the dead individuals were counted and left till the end of experiment.

\subsection{Statistical analysis}

To test the null hypothesis that Bt exposure at different concentrations had no effect on eco-physiological rates of two bivalves and on energy available for growth and reproduction (Scope for Growth), a mixed design ANOVA test (Underwood, 1997) was performed. Accordingly, CR, ER and RR, AE and SFG were analysed using Species (2 levels) and Bt exposure (FD, AD and CTRL) as fixed factors in the analysis, while Aquaria (Aquarium, 2 levels) was a random factor nested in Species $\times$ Bt. Eight animals $(n=8)$ were used as replicates in the analysis of eco-physiological rates. Instead, to perform the Heart Beat rate (HBR) ANOVA, Species (2 levels) and Bt exposure (FD, AD and CTRL) were fixed factors in the analysis and 6 animals were used as replicates. When significant differences were detected, the Student-Newman-Keuls (SNK) post-hoc pairwise comparison of means was used (Underwood, 1997). Cochran's test was used prior to ANOVA to test the assumption of homogeneity of variances (Underwood, 1997). When no homogeneous variances were rendered with any type of transformation, the significance level was set at 0.01 instead of 0.05 , as ANOVA can withstand variance heterogeneity, particularly in large balanced experiments, thereby reducing the possibility of a Type I error (Underwood, 1997).

\section{Results}

Feeding rates expressed as clearance rate were significantly different in both species under different experimental conditions. Indeed, with no Bt-pesticide the $\mathrm{CR}$ values in both species were generally higher than in the presence of $\mathrm{Bt}(P<0.05$; Table 1 ; Fig. 1$)$. Results for the two bivalve species differed significantly (ANOVA, $P<0.05$; Table 1; Fig. 1 ) at both control (CTRL) and field dose (FD), while their clearance rates were similar at the accumulation dose (AD) (ANOVA, $P>0.05$; Table 1; Fig. 1 ). A similar pattern for both species was also evident for the respiration rate (Table 1; Fig. 2). Instead, for $A D$, the respiration rates were higher for both species; indeed, with $\mathrm{Bt}$, the oxygen consumption in M. minimus showed a significant (ANOVA $P<0.05$; Fig. 2) linear increase. In contrast, the oxygen consumption of $B$. pharaonis increased from the control to FD, while it successively decreased from FD to AD (ANOVA, $P<0.05$; Table 1; Fig. 2). In both species the standardised excretion rates (ER st) did not show any significant differences between treatments (ANOVA, $P>0.05$; Table 1 ; Fig. 3 ), although excretion rates in Mytilaster were generally higher than in Brachidontes both under CTRL and AD treatments. The two species showed significant differences in the amount of standardised absorbed energy (AE) in CTRL (ANOVA, $P<0.05$; Table 1 ; Fig. 4), while they absorbed a similar amount of energy when they were in the presence of $\mathrm{Bt}$ (FD vs AD; ANOVA, $P>0.05$; Table 1; Fig. 4). Under different treatments, $M$. minimus did not show significant difference in $\mathrm{AE}$ values, while in $B$. pharaonis AE was significantly higher in CTRL with respect to the pesticide conditions. Bt presence had 
Table 1

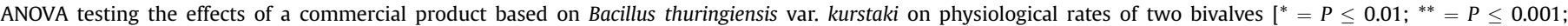
${ }^{* * *}=P \leq 0.000 ; \mathrm{ns}=$ no significant difference $\left.(P>0.01)\right]$.

\begin{tabular}{|c|c|c|c|c|c|c|c|c|c|c|c|c|}
\hline \multirow[t]{2}{*}{ Source } & \multirow[t]{2}{*}{$\mathrm{d} f$} & & \multicolumn{3}{|l|}{ CR st } & \multicolumn{3}{|l|}{ RR st } & & \multicolumn{3}{|l|}{ ER st } \\
\hline & & & MS & $F$ & $P$ & MS & $F$ & $P$ & & MS & $F$ & $P$ \\
\hline Species (Sp) & 1 & & 3.66 & 17.35 & $* *$ & 20.2 & 62.34 & $* *$ & & 48.52 & 54.99 & $* * *$ \\
\hline B. thuringiensis (Bt) & 2 & & 2.23 & 10.6 & * & 28.49 & 87.93 & $* *$ & & 0.24 & 0.27 & ns \\
\hline Aquarium $(\mathrm{Sp} \times \mathrm{Bt})$ & 6 & & 0.21 & 1.57 & ns & 0.32 & 1.77 & ns & & 0.88 & 2.83 & ** \\
\hline $\mathrm{Sp} \times \mathrm{Bt}$ & 2 & & 0.06 & 0.28 & ns & 6.15 & 18.98 & $* *$ & & 2.98 & 3.37 & ns \\
\hline Residuals & 84 & & 0.13 & & & 0.18 & & & & 0.31 & & \\
\hline Cochran's C & & & & & * & & & *sqr & & & & ns $(\log x)$ \\
\hline \multirow[t]{2}{*}{ Source } & \multirow{2}{*}{\multicolumn{2}{|c|}{$\mathrm{d} f$}} & & \multicolumn{4}{|l|}{ AR } & & \multicolumn{4}{|l|}{ SFG } \\
\hline & & & & MS & & $F$ & $P$ & & MS & & $F$ & $P$ \\
\hline Species (Sp) & & 1 & & 52.1 & & 8.81 & $*$ & & 67.26 & & 9.61 & $*$ \\
\hline B. thuringiensis (Bt) & & 2 & & 78.05 & & 13.19 & $* *$ & & 660.5 & & 94.35 & $* *$ \\
\hline Aquarium $(\mathrm{Sp} \times \mathrm{Bt})$ & & 6 & & 5.92 & & 1.88 & ns & & 7 & & 1.26 & ns \\
\hline $\mathrm{Sp} \times \mathrm{Bt}$ & & 2 & & 7.89 & & 1.33 & ns & & 108.9 & & 15.56 & $*$ \\
\hline Residuals & & 84 & & 3.14 & & & & & 5.54 & & & \\
\hline Cochran's C & & & & & & & $*$ & & & & & * \\
\hline
\end{tabular}

a significant effect on SFG in that the $M$. minimus values decreased linearly with Bt doses (ANOVA, $P<0.05$; Table 1 ; Fig. 5).

Heart beat rates (HBR) measured under Bt conditions were significantly higher than control (ANOVA, $P<0.05$; Table 1 ; Fig. 6 ) in both species, while a significant difference between species was detected for the control (Fig. 6).

Lastly, the two species' mortality differed with respect to the treatments with Bt: B. pharaonis was less influenced (5\% of individuals died after $48 \mathrm{~h}$ of exposure). In contrast, most $M$. minimus had already died after $24 \mathrm{~h}$ of treatment ( $72.5 \%$ of total) and almost no animal remained alive after $48 \mathrm{~h}$ (Table 2 ).

\section{Discussion}

A general acute detrimental effect on two target mussels of a commercial biopesticide based on entomopathogenic bacterium B. thuringiensis (Bt) was evident at the utilised doses. The effect on our mussels is difficult to frame within a general context as, to date, little research has been carried out on the effect of microbial pesticides on marine organisms.

These recent findings corroborate the idea that sessile suspension feeders like mussels, oysters, clams and cockles may be used as

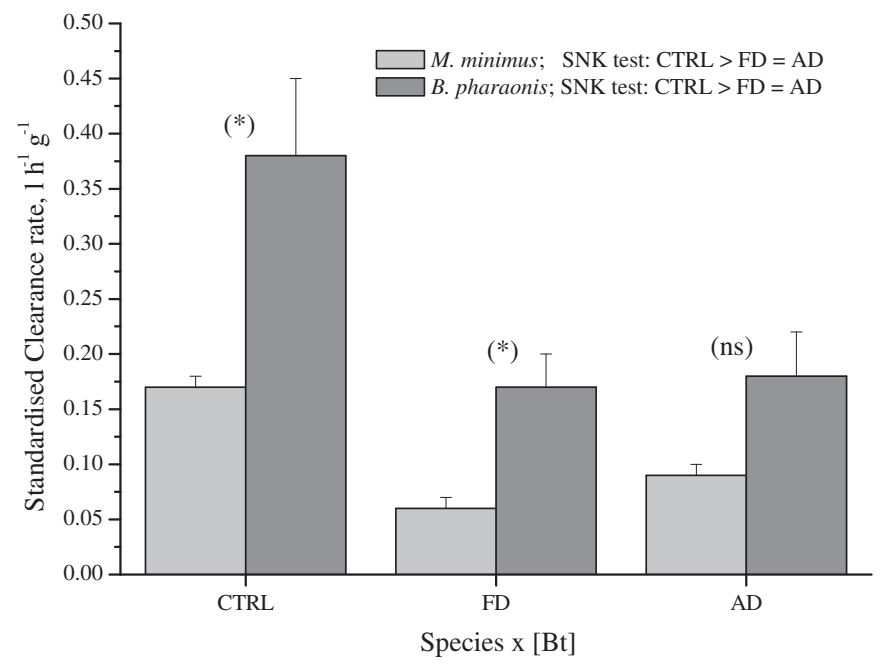

Fig. 1. Clearance rates of both species at varying Bt concentrations; $\mathrm{FD}=45 \mu \mathrm{L} \mathrm{L}^{-1}$, $\mathrm{AD}=90 \mu \mathrm{L} \mathrm{L}^{-1}$, CTRL $=$ control. elective candidates to assess the effect of contamination in aquatic environments (Widdows and Donkin, 1992). Indeed, since the Sixties, with the International Biological Program (IBP; the first coordinated large-scale ecological and environmental set of studies adopted by many countries worldwide), bivalves and, more specifically mussels, have been considered focal species, and have often been adopted as indicators in environmental risk assessment (Halldórsson et al., 2007). In the case of mussels, microbial Bt products would be assimilated through food acquisition mechanisms, since the size of $\mathrm{Bt}$ spores should fall well within the dimensional range of preferred bivalve food (from about $1 \mu \mathrm{m}$ to over 90-100 $\mu \mathrm{m}$; Dame, 1996). This is in agreement with the feeding habits of most marine bivalves, which get their energy from food in the form of particles found in water, including amorphous detritus, small unicellular suspended algae (e.g., phytoplankton) and both auto- and etero-trophic bacteria (Langdon and Newell, 1990; Sarà, 2006, 2007a). Our data are, to our knowledge, the first regarding the effect on marine bivalves, and are consistent with findings related to other species, both aquatic and terrestrial. Although with some species-specific differences, both investigated species were detrimentally affected in their ecological (i.e., feeding rates) and metabolic responses (e.g., respiration). While the difference between

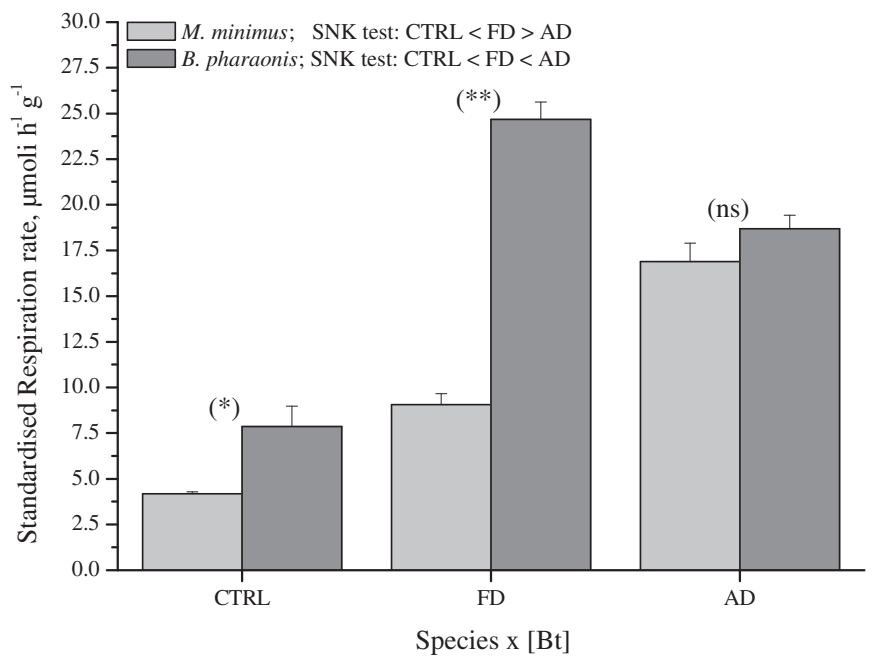

Fig. 2. Respiration rates of both species at varying Bt concentrations; $F D=45 \mu \mathrm{L} \mathrm{L}^{-1}$, $\mathrm{AD}=90 \mu \mathrm{L} \mathrm{L}^{-1}$, CTRL $=$ control. 


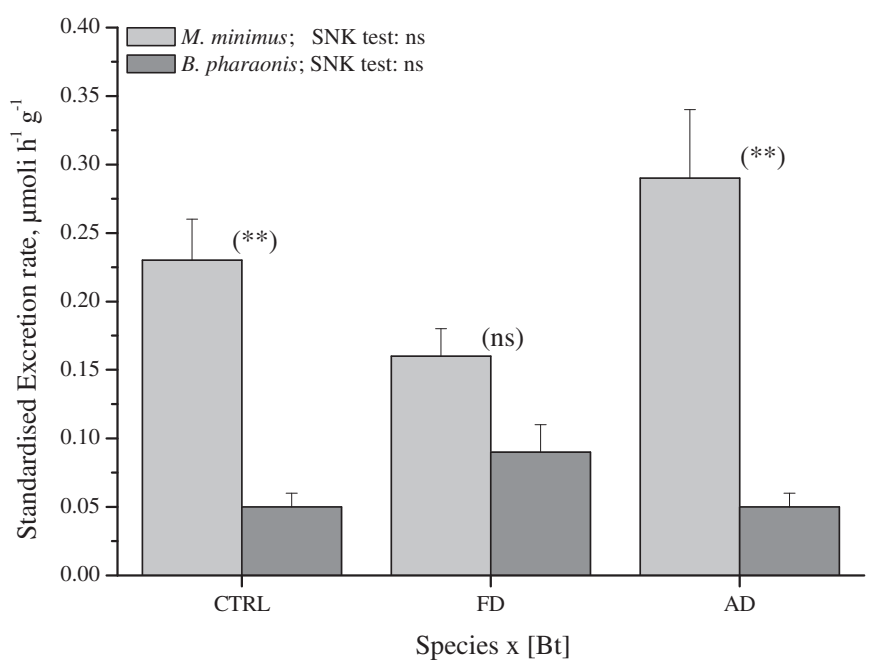

Fig. 3. Excretion rates of both species at varying Bt concentrations; $F D=45 \mu \mathrm{L} \mathrm{L}^{-1}$, $\mathrm{AD}=90 \mu \mathrm{L} \mathrm{L}^{-1}$, CTRL $=$ control.

clearance rates was negligible ( $54 \%$ vs $57 \%$ of the control rate, respectively; Table 3), the difference between respiration rates was higher in Mytilaster than Brachidontes (211\% vs 176\% of the control rate, respectively; Table 4). These different values of metabolic compensation should be linked to the superior ability of the invasive species to cope with more intensively negative conditions (sensu Mack et al., 2000). Although several questions have been raised and which need to be investigated in the future, it is important to notice that the Pharaonic mussel is considered one of the worst colonisers of the western Mediterranean Sea (Galil, 2007). Apart from possible species-specific differences, clearance rate (CR) values after $\mathrm{Bt}$ treatment were significantly lower than the controls, suggesting a shift from normal to worse (i.e., pejus) conditions (sensu Pörtner, 2010). A dependence of clearance on exogenous substances (e.g., pesticides, herbicides, PCB, DDT, TBT) has been described for many other bivalves, including Mytilus galloprovincialis (Cotou et al., 2001) and Mytilus edulis (Donkin et al., 1997; Widdows and Page, 1993) and the general effect was primarily a slight compensatory depression of behaviours and metabolic activities (within the pejus range). The late

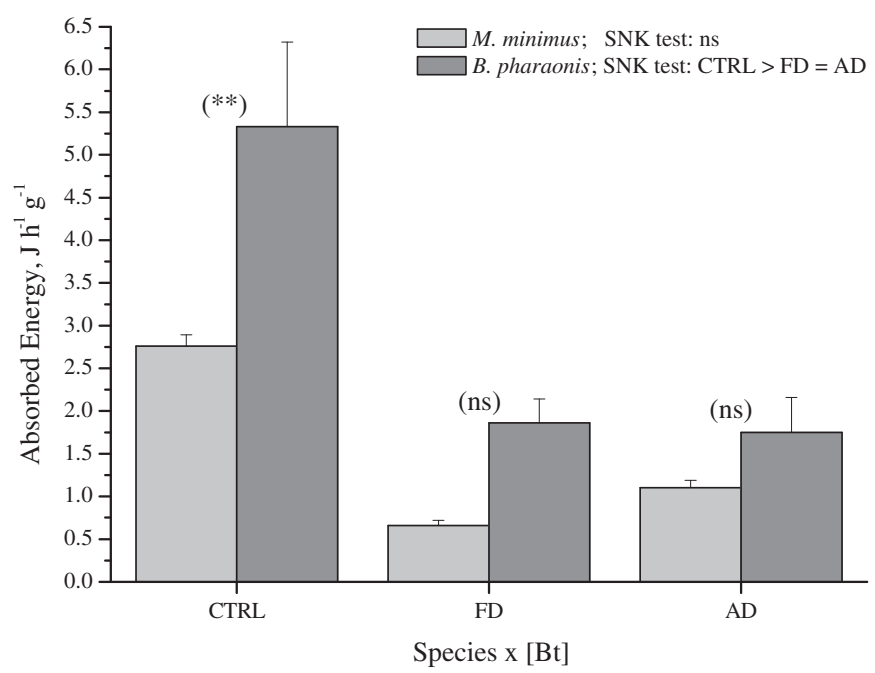

Fig. 4. Absorbed energy rates of both species at varying $\mathrm{Bt}$ concentrations; $\mathrm{FD}=45 \mu \mathrm{L} \mathrm{L}^{-1}, \mathrm{AD}=90 \mu \mathrm{L} \mathrm{L}^{-1}, \mathrm{CTRL}=$ control.

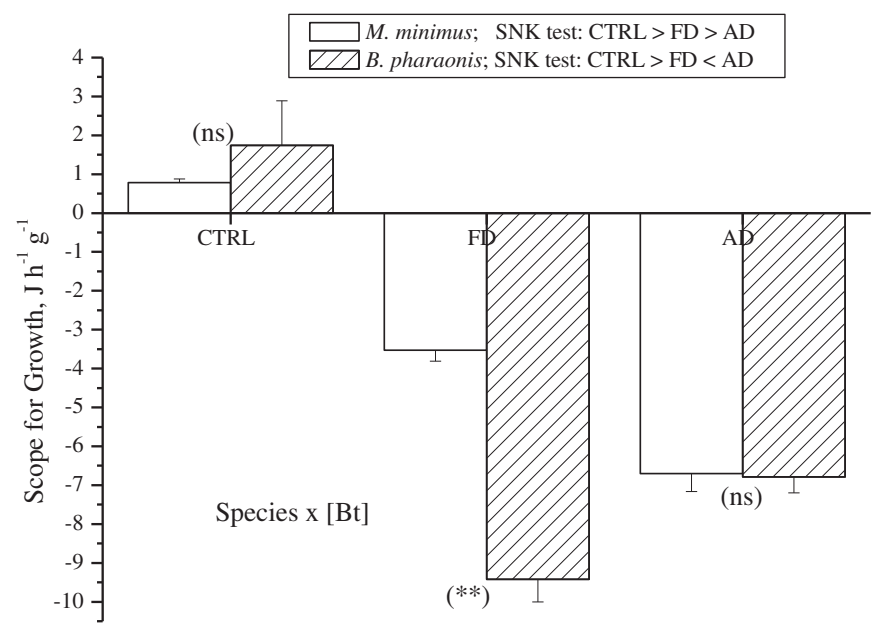

Fig. 5. Scope for Growth of both species at varying Bt concentrations; FD $=45 \mu \mathrm{L} \mathrm{L}^{-1}$, $\mathrm{AD}=90 \mu \mathrm{L} \mathrm{L}^{-1}$, CTRL $=$ control.

phase of response shows a conservatory decline or the general halting of all metabolic activities in order to assure somatic maintenance and to save energy for recovery, once the external conditions become favourable again (Sokolova and Pörtner, 2003).

In Tables 3 and 4, we have summarised the effect of the most common contaminants, both of chemical and biological origin, expressing the effect as a percentage of deviation from the control condition as indicated by the Authors. The research and analysis of literature were based on a procedure adopted in recent companion meta-analyses carried out on other topics (Sarà, 2007a, 2007b), and aid with the comparison of both the magnitude and the direction of effects among different species and contaminants. The general effect of contaminants on feeding behaviour (Table 3 ) was a depression of $C R$, which declined in all the tested species under the contaminants' effects. Bt induced a depression of CR in bivalves that was not comparable to the effect of Aroclor, TBT, DDT and PCB on Atlantic mussels (Cotou et al., 2001; Olsson et al., 2004), as they had effects at concentrations 3-6 times lower than Bt. Moreover the Bt effect was lower that of PAH on Japanese oysters (Kim et al.,

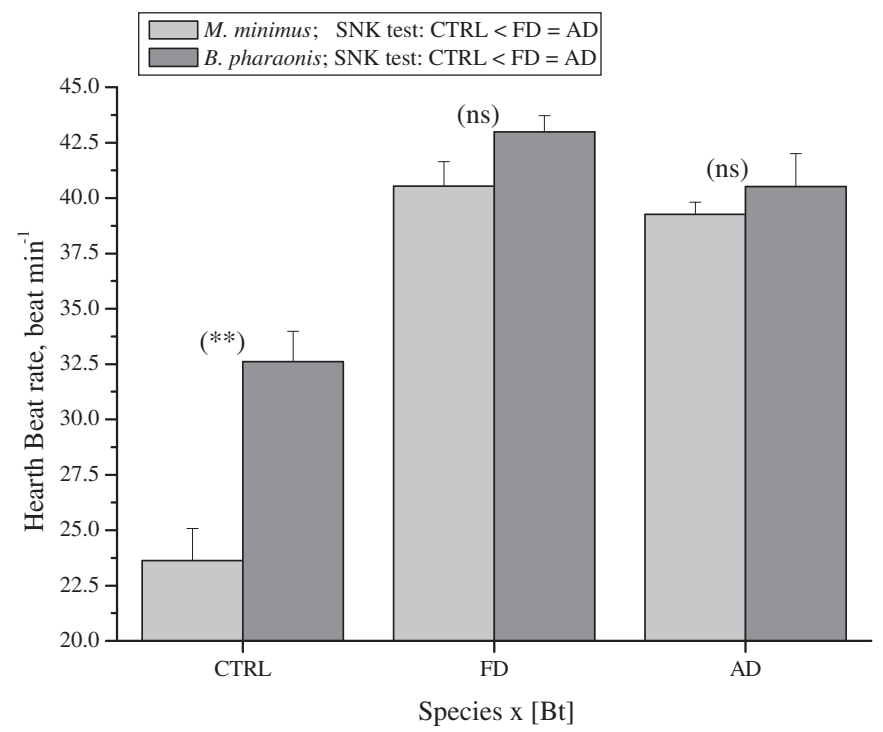

Fig. 6. Heart beat rates of both species at varying Bt concentrations; $F D=45 \mu \mathrm{L} \mathrm{L}^{-1}$, $\mathrm{AD}=90 \mu \mathrm{L} \mathrm{L}^{-1}, \mathrm{CTRL}=$ control. 
Table 2

Percentage of individuals that died following exposure to a commercial product containing Bacillus thuringiensis var. kurstaki.

\begin{tabular}{llcc}
\hline Species & $\begin{array}{l}\text { Conc of } \\
\text { BT }(\mu \mathrm{L} / \mathrm{L})\end{array}$ & $\begin{array}{l}\text { \% of individuals } \\
\text { dead after } 24 \mathrm{~h}\end{array}$ & $\begin{array}{c}\text { \% of individuals } \\
\text { dead after } 48 \mathrm{~h}\end{array}$ \\
\hline M. minimus & 45 & 0 & 5 \\
M. minimus & 90 & 72.5 & 23 \\
B. pharaonis & 45 & 0 & 0 \\
B. pharaonis & 90 & 0 & 5 \\
\hline
\end{tabular}

2007) and the of organochlorine on M. edulis (Widdows and Donkin, 1992). The present negative effect of Bt on CR could be due to a mechanical constraint of the filtration system caused by excessive mucus production that could occlude the gill cilia, as has been observed in other species (Canty et al., 2006; Snoeij et al., 1987; Widdows and Page, 1993; Zhen et al., 2010).

The effect of contaminants on the bivalve respiration function tended towards both an increase and depression, depending on the species and contaminants used (Table 4). Specifically, in our bivalves, Bt induced a significant effect of increased oxygen consumption, with a magnitude comparable to that of Methamidophos at lower concentrations, while Methamidophos induced a decrease in respiration rate when used at field application doses. An increment of RR in M. edulis was observed also in the case of PCBs and PHAs found at very low concentrations (pg and ng) (Table 4). The oxygen consumption of M. minimus increased proportionally with increasing Bt doses (although more concentration points would be necessary to verify the linearity of that relationship), showing a greater sensitivity of M. minimus than B. pharaonis, in that maximum RR values were reached after exposure to field doses (RR for B. pharaonis at field and accumulation concentrations of $\mathrm{Bt} \sim 25$ and $\sim 18 \mu$ moles $\mathrm{O}_{2} \mathrm{~h}^{-1}$ respectively). Also HBR, ER and the absorbed energy were negatively affected; these variables are all strictly related to processes of intake and energy use and their deviation from natural patterns, as indicated by CTRL, and imply repercussions on organismal energy balance (as expressed by SFG).

\subsection{General implications, caveats and concluding remarks}

Our results indicate that Bt may have measurable effects on the marine environment. However, commercial products contain different compounds that work as co-formulants to stabilise and preserve the overtime pathogenic ability of Bt. Products based on Bt contain a large percentage of bacteria and fermentation media. However other additives are used to improve product stability and provide other desirable characteristics like fluidity. Formulations of pesticides are closely guarded trade secrets, but for registration approval they must be provided to the appropriate government authorities (in the U.S, the E.P.A.). While we are aware that the effect of co-formulants on organisms could mask the realistic effect of Bt alone on physiological and metabolic aspects of our bivalves, our main aim was to study the composition and effects of the compounds that indeed reach the ultimate habitat (e.g., coastal ponds or intertidal pools).

For risk analysis, the OECD regulations consider all exposed environmental compartments and non-target species (OECD, 2007). On the other hand, risk assessment strategies should take into consideration realistic environmental exposure. However, the runoff and the fate of microbial products, which could be metabolised by organisms and channelled through food webs, is actually difficult to predict (sensu Laengle and Strasser, 2010; Gagné et al., 2006; Douville et al., 2007, 2009). Bt can enter the aquatic environment indirectly, through runoff or over-spray, through water, or through the feces of animals (Joung and Coté, 2000), through the control of pests such as mosquitos or snails (Charudattan et al., 1990; Pouline et al., 2010), and also via detritus, which is the main food item of many marine organisms like the bivalves tested in the present paper, but also of worms, crabs, sea stars and fish (sensu Pearson and Callaway, 2003, 2005; Singer et al., 1994). Since

Table 3

Effects of the most common contaminants, both of chemical and biological origin, on the clearance rate of bivalves.

\begin{tabular}{|c|c|c|c|c|c|c|}
\hline Paper & Species & Size $(\mathrm{mm})$ & Contaminant & Unit & $\begin{array}{l}\text { Direction } \\
\text { of effect }\end{array}$ & $\begin{array}{l}\text { \% of variation } \\
\text { respect to CTRL }\end{array}$ \\
\hline Sobral and Widdows, 1997 & Ruditapes philippinarum & 32.5 & $\mathrm{Cu}(0.01 \mathrm{mg} / \mathrm{l})$ & $\mathrm{L} / \mathrm{h}$ & Down & 54.4 \\
\hline Olsson et al., 2004 & Mytilus edulis & $18-23$ & Aroclor & $\mathrm{L} / \mathrm{g} \mathrm{h}$ & Down & 51.3 \\
\hline Olsson et al., 2004 & Mytilus edulis & $19-23$ & IgPCB & $\mathrm{L} / \mathrm{g} \mathrm{h}$ & Down & 47.8 \\
\hline Olsson et al., 2004 & Mytilus edulis & $20-23$ & Ig PAH & $\mathrm{L} / \mathrm{g} \mathrm{h}$ & Down & 30.9 \\
\hline Olsson et al., 2004 & Mytilus edulis & $21-23$ & SR5 PCB & $\mathrm{L} / \mathrm{g} \mathrm{h}$ & Down & 30.2 \\
\hline Olsson et al., 2004 & Mytilus edulis & $22-23$ & SR5PAH & $\mathrm{L} / \mathrm{g} \mathrm{h}$ & Down & 23.7 \\
\hline Kim et al., 2007 & Crassostrea gigas & $50-140$ & $\mathrm{PAH}(50 \mu \mathrm{g} / \mathrm{L})$ & $\mathrm{L} / \mathrm{h}$ & Up & 0.9 \\
\hline Kim et al., 2007 & Crassostrea gigas & $51-140$ & PAH $(100 \mu \mathrm{g} / \mathrm{L})$ & $\mathrm{L} / \mathrm{h}$ & Down & 68.2 \\
\hline Kim et al., 2007 & Crassostrea gigas & $52-140$ & PAH $(200 \mu \mathrm{g} / \mathrm{L})$ & $\mathrm{L} / \mathrm{h}$ & Down & 79.1 \\
\hline Cotou et al., 2001 & Mytilus galloprovincialis & 40 & DDT - herbicide - PCB & $\mathrm{L} / \mathrm{g} \mathrm{h}$ & Down & 20.9 \\
\hline Cotou et al., 2001 & Mytilus galloprovincialis & 40 & DDT - herbicide - PCB & $\mathrm{L} / \mathrm{g} \mathrm{h}$ & Down & 72.8 \\
\hline Cotou et al., 2001 & Mytilus galloprovincialis & 40 & DDT - herbicide - PCB & $\mathrm{L} / \mathrm{g} \mathrm{h}$ & Down & 57.4 \\
\hline Cotou et al., 2001 & Mytilus galloprovincialis & 40 & DDT - herbicide - PCB & $\mathrm{L} / \mathrm{g} \mathrm{h}$ & Down & 74.1 \\
\hline Donkin et al., 1997 & Mytilus edulis & $35-40$ & Organochlorine $(1.5 \mathrm{mg} / \mathrm{l})$ & - & Down & 100 \\
\hline Donkin et al., 1997 & Mytilus edulis & $35-40$ & $\begin{array}{l}\text { Pesticide (organofosfat - carbamate) } \\
300 \mu \mathrm{g} / \mathrm{L}\end{array}$ & - & Down & 40 \\
\hline Halldórsson et al., 2007 & Mytilus edulis & $45-50$ & Benzo[a] pyrene & $\mathrm{L} / \mathrm{g} \mathrm{h}$ & Down & 7.3 \\
\hline Halldórsson et al., 2007 & Mytilus edulis & $45-50$ & Benzo[a] pyrene & $\mathrm{L} / \mathrm{g} \mathrm{h}$ & Up & 31.7 \\
\hline Widdows and Page, 1993 & Mytilus edulis & 40 & TBT & $\mathrm{L} / \mathrm{h}$ & Down & 79.92 \\
\hline Widdows and Page, 1993 & Mytilus edulis & 40 & DBT & $\mathrm{L} / \mathrm{h}$ & Down & 47.8 \\
\hline Abel, 1976 & Mytilus edulis & $30-50$ & $\mathrm{Cu}$ & $\mathrm{ml} / \mathrm{min}$ & Down & 59.6 \\
\hline Abel, 1976 & Mytilus edulis & $30-50$ & $\mathrm{Zn}$ & $\mathrm{ml} / \mathrm{min}$ & Down & 54 \\
\hline Canty et al., 2006 & Mytilus edulis & $40-60$ & Acetone & $\mathrm{L} / \mathrm{h}$ & Down & 13.4 \\
\hline Canty et al., 2006 & Mytilus edulis & $40-60$ & Azamethiphos & $\mathrm{L} / \mathrm{h}$ & Down & 7.8 \\
\hline Present Study & Brachidontes pharaonis & 30 & EG $2424(45 \mu \mathrm{L} / \mathrm{L})$ & $\mathrm{L} / \mathrm{g} \mathrm{h}$ & Down & 54.58 \\
\hline Present Study & Brachidontes pharaonis & 30 & EG $2424(90 \mu \mathrm{L} / \mathrm{L})$ & $\mathrm{L} / \mathrm{g} \mathrm{h}$ & Down & 53.28 \\
\hline Present Study & Mytilaster minimus & 11 & EG $2424(45 \mu \mathrm{L} / \mathrm{L})$ & $\mathrm{L} / \mathrm{g} \mathrm{h}$ & Down & 63.11 \\
\hline Present Study & Mytilaster minimus & 11 & EG $2424(90 \mu \mathrm{L} / \mathrm{L})$ & $\mathrm{L} / \mathrm{g} \mathrm{h}$ & Down & 49.83 \\
\hline
\end{tabular}


Table 4

Effects of the most common contaminants of both chemical and biological origins, on the respiration rate of bivalves.

\begin{tabular}{|c|c|c|c|c|c|c|}
\hline Paper & Species & Size $(\mathrm{mm})$ & Contaminant & Unit & $\begin{array}{l}\text { Direction } \\
\text { of effect }\end{array}$ & $\begin{array}{l}\% \text { of variation } \\
\text { respect to CTRL }\end{array}$ \\
\hline Sobral and Widdows, 1997 & Ruditapes philippinarum & 32.5 & $\mathrm{Cu}(0.01 \mathrm{mg} / \mathrm{l})$ & & Up & 33.4 \\
\hline Olsson et al., 2004 & Mytilus edulis & $18-23$ & Aroclor & & Up & 31.7 \\
\hline Olsson et al., 2004 & Mytilus edulis & $19-23$ & $\operatorname{IgPCB}$ & & Up & 19 \\
\hline Olsson et al., 2004 & Mytilus edulis & $20-23$ & Ig PAH & & No & 0 \\
\hline Olsson et al., 2004 & Mytilus edulis & $21-23$ & SR5 PCB & & Down & 7.9 \\
\hline Olsson et al., 2004 & Mytilus edulis & $22-23$ & SR5PAH & & Up & 1.6 \\
\hline Kim et al., 2007 & Crassostrea gigas & $50-140$ & $\mathrm{PAH}(50 \mu \mathrm{g} / \mathrm{L})$ & $\mathrm{ml} / \mathrm{h}$ & Up & 11 \\
\hline Kim et al., 2007 & Crassostrea gigas & $51-140$ & PAH $(100 \mu \mathrm{g} / \mathrm{L})$ & $\mathrm{ml} / \mathrm{h}$ & Up & 6.5 \\
\hline Kim et al., 2007 & Crassostrea gigas & $52-140$ & $\mathrm{PAH}(200 \mu \mathrm{g} / \mathrm{L})$ & $\mathrm{ml} / \mathrm{h}$ & Down & 5.5 \\
\hline Cotou et al., 2001 & Mytilus galloprovincialis & 40 & DDT - herbicide - PCB & $\mu \mathrm{mol} / \mathrm{g} \mathrm{h}$ & Down & 40.9 \\
\hline Cotou et al., 2001 & Mytilus galloprovincialis & 40 & DDT - herbicide - PCB & $\mu \mathrm{mol} / \mathrm{g} \mathrm{h}$ & Down & 43.7 \\
\hline Cotou et al., 2001 & Mytilus galloprovincialis & 40 & DDT - herbicide - PCB & $\mu \mathrm{mol} / \mathrm{g} \mathrm{h}$ & Up & 0.7 \\
\hline Cotou et al., 2001 & Mytilus galloprovincialis & 40 & DDT - herbicide - PCB & $\mu \mathrm{mol} / \mathrm{g} \mathrm{h}$ & Down & 25.4 \\
\hline Widdows and Page, 1993 & Mytilus edulis & 40 & TBT & $\mu \mathrm{mol} / \mathrm{h}$ & Up & 39.4 \\
\hline Widdows and Page, 1993 & Mytilus edulis & 40 & DBT & $\mu \mathrm{mol} / \mathrm{h}$ & Down & 94 \\
\hline Zhen et al., 2010 & Mytilus edulis & 40 & Methamidophos $(1 \mu \mathrm{g} / \mathrm{L})$ & $\mathrm{mg} / \mathrm{g} \mathrm{h}$ & Up & 4.2 \\
\hline Zhen et al., 2010 & Mytilus edulis & 40 & Methamidophos $(10 \mu \mathrm{g} / \mathrm{L})$ & $\mathrm{mg} / \mathrm{g} \mathrm{h}$ & Up & 3.3 \\
\hline Zhen et al., 2010 & Mytilus edulis & 40 & Methamidophos $(50 \mu \mathrm{g} / \mathrm{L})$ & $\mathrm{mg} / \mathrm{g} \mathrm{h}$ & Down & 0.5 \\
\hline Zhen et al., 2010 & Mytilus edulis & 40 & Methamidophos $(100 \mu \mathrm{g} / \mathrm{L})$ & $\mathrm{mg} / \mathrm{g} \mathrm{h}$ & Down & 4.3 \\
\hline Zhen et al., 2010 & Mytilus edulis & 40 & Methamidophos $(200 \mu \mathrm{g} / \mathrm{L})$ & $\mathrm{mg} / \mathrm{g} \mathrm{h}$ & Down & 8.5 \\
\hline Present Study & Brachidontes pharaonis & 30 & EG $2424(200 \mu \mathrm{L})$ & $\mu \mathrm{mol} / \mathrm{g} \mathrm{h}$ & Up & 214.3 \\
\hline Present Study & Brachidontes pharaonis & 30 & EG $2424(400 \mu \mathrm{L})$ & $\mu \mathrm{mol} / \mathrm{g} \mathrm{h}$ & Up & 138.1 \\
\hline Present Study & Mytilaster minimus & 11 & EG $2424(200 \mu \mathrm{L})$ & $\mu \mathrm{mol} / \mathrm{g} \mathrm{h}$ & Up & 117.3 \\
\hline Present Study & Mytilaster minimus & 11 & EG $2424(400 \mu \mathrm{L})$ & $\mu \mathrm{mol} / \mathrm{g} \mathrm{h}$ & Up & 305.2 \\
\hline
\end{tabular}

there is scant information about the effects of Bt on marine invertebrates and its end-destination (Laengle and Strasser, 2010), our aim was to simulate the worse scenarios possible using an average dose applied to fields (FD) and a hypothetical accumulation dose (AD). Acute exposure deriving from present doses resulted in a sublethal effect involving some physiological aspects. While there is an urgent need to address the role of international trade in government strategies to prevent species introduction (Essl et al., 2011), we highlight the need, in addition, to regulate the use, in all countries, of potential products like chemical and bio-pesticides that can enhance the likelihood of colonising new species that would produce very evident effects on local diversity. Our results, as part of the development of sustainable biopesticides, can provide additional information on community ecology and biological invasions, as invoked specifically by Directive 92/43/EEC, Directive 2000/60/EC and Pearson and Callaway (2003, 2005).

Moreover, by 14 December 2012, the EU Commission, in cooperation with its Member States, will have developed a strategic guidance document for the monitoring and surveying of the impact of the use of plant protection products (including biopesticides) on human health and the environment. Community action (Directive 2009/128/EC) to promote sustainable use should complement other related Community legislation such as Directive 92/43/EEC on the conservation of natural habitats and of wild fauna and flora and Directive 2000/60/EC on the regulation of policies related to water. However, only recently has the impact of agriculture on marine biodiversity received real attention, showing, as in the present case, that it is difficult for marine coastal areas to remain unaffected by human actions. Accordingly, Halpern et al. (2008), and more recently Stuart (2010), estimated that large fractions (over $40 \%$ ) of coastal areas are impacted by multiple drivers which include agricultural products. However, new concepts and ideas on environmental pollution are emerging (e.g., biological pollution) with a corresponding need for updating current knowledge (Firbank et al., 2008; Matson et al., 1997; Schlesinger, 1991).

Thus the use of ecologically-based management strategies that also consider ecological responses at organismal levels should help increase the sustainability of agricultural production, reducing offsite consequences.

\section{Acknowledgements}

This paper has been partially inspired and sustained by INTERMED in the framework of the Circle ERA Net project (funded by the European Commission 6th Framework Programme) and PRIN 2008 n. 200847CA28_002. We are grateful to the students of the Experimental Ecology Lab for their help in the collection of date during mesocosm experiments.

\section{References}

Abel, P.D., 1976. Effect of some pollutants on the filtration rate of Mytilus edulis. Mar. Pollut. Bull. 7, 228-231.

Bayne, B.L., 2004. Phenotypic flexibility and physiological tradeoffs in the feeding and growth of marine bivalve molluscs. Integr. Comp. Biol. 44, 425-432.

Boisvert, M., Boisvert, J., 2000. Effects of Bacillus thuringiensis var israelensis on target and non-target organisms: a review of laboratory and field experiments. Biocontrol. Sci. Technol. 10, 517-561.

Callow, M.E., Willingham, G.L., 1996. Degradation of antifouling biocides. Biofouling $10,239-249$.

Canty, M.N., Hagger, J.A., Moore, R.T.B., Cooper, L., Galloway, T.S., 2006. Sublethal impact of short term exposure to the organophosphate pesticide azamethiphos in the marine mollusc Mytilus edulis. Mar. Pollut. Bull. 54, 396-402.

Catalano, G., 1987. An improved method for the determination of ammonia in seawater. Mar. Chem. 20, 289-295.

Cervino, J.M., Winiarski-Cervino, K., Polson, S.W., Goreau, T.J., Smith, G.W., 2006. Identification of bacteria associated with a disease affecting the sponge Ianthella basta, in New Britain, Papua New Guinea. Mar. Ecol. Prog. Ser. 324, 139-150.

Charudattan, R., De Valerio, J.T., Prange, V.J., 1990. Special problems associated with aquatic weed control. In: Baker, R., Dunn, P.E. (Eds.), New Directions in Biological Control: Alternatives for Suppressing Agricultural Pests and Diseases. Alan R., Liss, New York, pp. 287-303.

Clynick, B.G., Blockley, D., Chapman, M.G., 2009. Anthropogenic changes in pattern of diversity on hard substrata: an overview. In: Wahl, Martin (Ed.), Marine Hard Bottom Communities Patterns, Dynamics, Diversity and Change. Springer-Verlag, Berlin Heidelberg, pp. 247-256.

Conover, R.J., 1966. Assimilation of organic matter by zooplankton. Limnol. Oceanogr. 11, 338-354.

Cotou, E., Papathanassiou, E., Tsangaris, C., 2001. Assessing the quality of marine coastal environments: comparison of scope for growth and Microtox bioassay results of pollution gradient areas in eastern Mediterranean (Greece). Environ. Pollut. 119, 141-149.

Dame, R., 1996. Ecology of marine bivalves: an ecosystem approach. In: Kennish, M.J., Lutz, P.L. (Eds.), CRC Marine Series. CRC Press, Boca Raton London, New York, Washington D.C., pp. 1-254.

Depledge, M.H., Anderson, B.B., 1990. A computer-aided physiological monitoringsystem for continuous, long-term recording of cardiac activity in selected invertebrates. Comp. Biochem. Physol. 96, 473-477. 
Directive 2000/60/EC, October 2000. Establishing a framework for community action in the field of water policy. Off. J. Eur. Union L327, 1-65.

Directive 2009/128/EC, October 2009. Establishing a framework for community action to achieve the sustainable use of pesticide. Off. J. Eur. Union L309, $71-83$.

Directive 92/43/EEC, May 1992. On the conservation of natural habitats and of wild fauna and flora. Off. J. Eur. Communities L206, 7-50.

Dondero, F., Banni, M., Negri, A., Boatti, L., Dagnino, A., Viarengo, A., 2011. Interactions of a pesticide/heavy metal mixture in marine bivalves: a transcriptomic assessment BMC. Genomics 12, 195-212.

Dong, Y., Williams, G., 2011. Variations in cardiac performance and heat shock protein expression to thermal stress in two differently zoned limpets on a tropical rocky shore. Mar. Biol. 158, 1223-1231.

Donkin, P., Widdows, J., Evans, S.V., Staff, F.J., Yan, T., 1997. Effects of neurotoxic pesticides on the feeding rate of marine mussels (Mytilus edulis). Pestic. Sci. 49, 196-209.

Douville, M., Gagne, F., Blaise, C., Andre, C., 2007. Occurrence and persistence of Bacillus thuringiensis $(\mathrm{Bt})$ and transgenic $\mathrm{Bt}$ corn cry1 $\mathrm{Ab}$ gene from an aquatic environment. Ecotoxicol. Environ. Saf. 66, 195-203.

Douville, M., Gagne, F., Andre, C., Blaise, C., 2009. Occurrence of the transgenic corn cry $1 \mathrm{Ab}$ gene in freshwater mussels (Elliptio complanata) near corn fields: evidence of exposure by bacterial ingestion. Ecotoxicol. Environ. Saf. 72, $17-25$.

Duchet, C., Caquet, T., Franquet, E., Lagneau, C., Lagadic, L., 2010. Influence of environmental factors on the response of a natural population of Daphnia magna (Crustacea: Cladocera) to spinosad and Bacillus thuringiensis israelensis in Mediterranean coastal wetlands. Environ. Pollut. 158, 1825-1833.

Eder, E., Schönbrunner, I., 2010. Toxicity of Bacillus thuringiensis israelensis on the non target organisms Triops cancriformis, Branchipus schaefferi, Leptestheria dahalacensis (Crustacea: Branchiopoda: Notostraca, Anostraca, Spinicaudata). Open Environ. Pollut. Toxicol. J. 2, 16-20.

Essl, F., Mang, T., Dullinger, S., Moser, D., Hulme, P.E., 2011. Macroecological drivers of alien conifer naturalizations worldwide. Ecography 34, 1076-1084.

Ezgeta-Balic, D., Rinaldi, A., Peharda, M., Prusina, I., Montalto, V., Niceta, N., Sarà, G., 2011. An energy budget of the subtidal bivalve, Modiolus barbatus (Mollusca) at different temperatures. Mar. Environ. Res. 71, 79-85.

FAO, 2010. The State of Food and Agriculture. http://www.fao.org/docrep/013/ i2050e/i2050e.pdf.

Firbank, L.G., Petit, S., Smart, S., Blain, A., Fuller, R.J., 2008. Assessing the impacts of agricultural intensification on biodiversity: a British perspective. Phil. Trans. $R$ Soc. B 363, 777-787.

Fischer, P., 1870. Sur la Faune conchyliologique marine des baies de Suez et de l'Akabah. J. Conchyliol. 13, 178-179.

Fourcy, D., Jumel, A., Heydorff, M., Lagadic, L., 2002. Esterases as biomarkers in Nereis (Hediste) diversicolor exposed to temephos and Bacillus thuringiensis var israelensis used for mosquito control in coastal wetlands of Morbihan (Brittany, France). Mar. Environ. Res. 54, 755-759.

Gagnaire, B., Thomas-Guyon, H., Burgeot, T.H., Renault, T., 2006. Pollutant effects on Pacific oyster, Crassostrea gigas (Thunberg), hemocytes: screening of 23 molecules using flow cytometry. Cell. Biol. Toxicol. 22, 1-14.

Gagné, F., Blaise, C., Fournier, M., Hansen, P.D., 2006. Effects of selected pharmaceutical products on phagocytic activity in Elliptio complanata mussels. Comp. Biochem. Physiol. C Toxicol. Pharmacol. 143, 179-186.

Galil, B.S., 2007. Seeing Reed: Alien species along the Mediterranean coast of Israel. Aquat. Inv 2, 281-312.

Gutierrez, J.L., Jones, C.G., Strayer, D.L., Iribarne, O.O., 2003. Mollusks as ecosystem engineers: the role of shell production in aquatic habitats. Oikos 101, 79-90.

Halldórsson, H.P., De Pirro, M., Romano, C., Svavarsson, J., Sarà, G., 2007. Immediate biomarker responses to benzo[a]pyrene in polluted and unpolluted populations of the blue mussel (Mytilus edulis L) at high-latitudes. Environ. Int. 34, 483-489.

Halpern, B.S., Walbridge, S., Selkoe, K.A., Kappel, C.V., Micheli, F., D’Agrosa, C., Bruno, J.F., Casey, K.S., Ebert, C., Fox, H.E., Fujita, R., Heinemann, D., Lenihan, H.S., Madin, E.M.P., Perry, M.T., Selig, E.R., Spalding, M., Steneck, R., Watson, R., 2008. A global map of human impact on marine ecosystems. Science $319,948-952$.

Jones, C.G., Lawton, J.H., Shachak, M., 1997. Positive and negative effects of organisms as physical ecosystem engineers. Ecology 78, 1946-1957.

Joung, K., Coté, J., 2000. A review of the environmental impacts of the microbial insecticide Bacillus thuringiensis. Tech. Bull. 29, 1-18.

Kim, M.C., Cho, S.M., Jeong, W.G., 2007. Short-term response of the Pacific oyster, Crassostrea gigas, on exposure to varying levels of polycyclic aromatic hydrocarbon. Aquac. Res. 38, 1612-1618.

Laengle, T., Strasser, H., 2010. Developing a risk indicator to comparatively assess environmental risks posed by microbial and conventional pest control agents. Biocontrol. Sci. Technol. 20, 659-681.

Langdon, C.J., Newell, R.I.E., 1990. Comparative utilization of detritus and bacteria as food sources by two bivalve suspension-feeders, the oyster Crassostrea virginica and the mussel, Geukensia demissa. Mar. Ecol. Prog. Ser. 58, 299310.

Mack, R.N., Simberloff, D., Lonsdale, W.M., Evans, H., Clout, M., Bazzaz, F.A., 2000. Biotic invasions: causes, epidemiology, global consequences and control. Ecol. Appl. 10, 689-710.

Manachini, B., Arizza, V., Parrinello, D., Parrinello, N., 2011. Hemocytes of Rhynchophorus ferrugineus (Olivier) (Coleoptera: Curculionidae) and their response to Saccharomyces cerevisiae and Bacillus thuringiensis. J. Invertbr. Pathol. 106 $360-365$.

Manachini, B., 2012. Pesticides: chemical and biological. In: Jorgensen, S.V. (Ed.), Encyclopedia of Environmental Management. Taylor \& Francis Books/Encyclopedias Program, New York, USA.

Manganaro, A., Pulicanò, G., Reale, A., Sanfilippo, M., Sarà, G., 2009. Filtration pressure by bivalves affects the trophic conditions in Mediterranean shallow ecosystems. Chem. Ecol. 25, 467-478.

Matson, P.A., Parton, W.J., Power, A.G., Swift, M.J., 1997. Agricultural intensification and ecosystem properties. Science 277, 504-509.

Menon, A.S., de Mestral, J., 1985. Survival of Bacillus thuringiensis var kurstaki in waters. Water Air Soil Pollut. 25, 265-274.

Negri, A.P., Soo, R.M., Flores, F., Webster, N.S., 2009. Bacillus insecticides are not acutely harmful to corals and sponges. Mar. Ecol. Prog. Ser. 381, 157-165.

OECD, 2007. Biological Pesticide Registration, Environment Directorate. http:// www.oecd.org/document/8/0, 2340, en_2649_34383_31962760_1_1_1_1,00. html (accessed June, 2011).

Olsson, B., Bradley, B.P., Gilek, M., Reimer, O., Shepard, J.L., Tedengren, M., 2004 Physiological and proteomic responses in Mytilus edulis exposed to PCBs and PAHs extracted from Baltic Sea sediments. Hydrobiologia 514, 15-27.

Pearson, D.E., Callaway, R.M., 2003. Indirect effects of host-specific biological control agents. Trends Ecol. Evol. 18, 456-461.

Pearson, D.E., Callaway, R.M., 2005. Indirect non-target effects of host-specific biological control agents: implications for biological control. Biol. Control 35, 288-298.

Pörtner, H., 2010. Oxygen and capacity limitation of thermal tolerance: a matrix for integrating climate related stressors in marine ecosystems. J. Exp. Biol. 213, 881-893.

Pouline, B., Lefebvre, G., Paz, L., 2010. Red flag for green spray: adverse trophic effects of Bt on breeding birds. J. Appl. Ecol. 47, 884-889.

Sarà, G., De Pirro, M., 2011. Heart beat rate adaptations to varying salinity of two intertidal Mediterranean bivalves: the invasive Brachidontes pharaonis and the native Mytilaster minimus. Italian J. Zool. 78, 193-197.

Sarà, G., Romano, C., Widdows, J., Staff, F.J., 2008. Effect of salinity and temperature on feeding physiology and scope for growth of an invasive species (Brachidontes pharaonis-Mollusca: Bivalvia) within the Mediterranean Sea. J. Exp. Mar. Biol. Ecol. 363, 130-136.

Sarà, G., Kearney, M., Helmuth, B., 2011. Combining heat-transfer and energy budget models to predict local and geographic patterns of mortality in Mediterranean intertidal mussels. Chem. Ecol. 27, 135-145.

Sarà, G., Reid, G., Rinaldi, A., Palmeri, V., Troell, M., Kooijman, S.A.L.M., 2012a Growth and reproductive simulation of candidate shellfish species at fish cages in the southern Mediterranean: dynamic energy budget (DEB) modelling for integrated multi-trophic aquaculture. Aquaculture 324-325, 259-266.

Sarà, G., Milanese, M., Prusina, I., Sarà, A., Angel, D.L., Glamuzina, B., Nitzan, T. Freeman, S., Rinaldi, A., Palmeri, V., Montalto, V., Lo Martire, M., Gianguzza, P., Arizza, V., Lo Brutto, S., De Pirro, M., Helmuth, B., Murray, J., De Cantis, S. Williams, G.A., 2012b. The impact of climate change on Mediterranean intertidal communities: losses in coastal ecosystem integrity and services. Regional Environ. Change. http://dx.doi.org/10.1007/s10113-012-0360-z.

Sarà, G., 2006. Hydrodynamic effect on the origin and quality of organic matter for bivalves: an integrated isotopic, biochemical and transplant study. Mar. Ecol. Prog. Ser. 328, 65-73.

Sarà, G., 2007a. The ecological effect of aquaculture on physical variables of the water column: a meta-analysis. Chem. Ecol. 23, 251-262.

Sarà, G., 2007b. A meta-analysis on the ecological effects of aquaculture on the water column: dissolved nutrients. Mar. Environ. Res. 63, 390-408.

Schlesinger, W.H., 1991. In: Schlesinger, W.H. (Ed.), Biogeochemistry: an Analysis of Global Change. Academic Press Inc., San Diego, p. 351.

Singer, S., Bair, T.B., Berte, A.M., Correa-Ochoa, M.M., Stambaugh, A.D., 1994 Fermentation and toxin studies of the molluscicidal strains of Bacillus brevis. J. Ind. Microbiol. 13, 112-119.

Snoeij, N.J., Penninks, A.H., Seinen, W., 1987. Biological activity of organotin compounds - an overview. Environ. Res. 44, 335-353.

Sobral, P., Widdows, J., 1997. Effects of copper exposure on the Scope for Growth of the clam Ruditapes decussatus from Southern Portugal. Mar. Pollut. Bull. 34, 992-1000.

Sokolova, I.M., Pörtner, H.O., 2003. Metabolic plasticity and critical temperatures for aerobic scope in a eurythermal marine invertebrate (Littorina saxatilis, Gastropoda: Littorinidae) from different latitudes. J. Exp. Biol. 206, 195-207.

Sousa, R., Gutiérrez, J.L., Aldridge, D.C., 2009. Non-indigenous invasive bivalves as ecosystem engineers. Biol. Invasions 11, 2367-2385.

Stuart, D., 2010. Coastal ecosystems and agricultural land use: new challenges on California's central coast. Coast Manage. 38, 42-64.

Surgeoner, G.A., Farkas, M.J., 1990. In: Surgeoner, G.A., Farkas, M.J. (Eds.), Review of Bacillus thuringiensis var kurstaki (Btk) for Use in Forest Pest Management Programs in Ontario-with Special Emphasis on the Aquatic Environment. Aquatic Criteria Development Committee Water Resources Branch, pp. 1-87.

Tilquin, M., Paris, M., Reynaud, S., Despres, L., Ravanel, P., Geremia, R.A., Gury, J., 2008. Long lasting persistence of Bacillus thuringiensis subsp israelensis (Bti) in mosquito natural habitats. PLoS ONE 3.

Underwood, A.J., 1997. Environmental decision-making and the precautionary principle: what does this principle mean in environmental sampling practice? Landscape Urban Plan. 37, 137-146.

Van Cuyk, S., Deshpande, A., Hollander, A., Duval, N., Ticknor, L., Layshock, J., Gallegos-Graves, L., Omberg, K.M., 2011. Persistence of Bacillus thuringiensis subsp 
kurstaki in urban environments following spraying. Appl. Environ. Microbiol. 77, 7954-7961.

Widdows, J., Donkin, P., 1992. Mussels and environmental contaminants: bioaccumulation and physiological aspects. In: Gosling, E. (Ed.), The Musse Mytilus: Ecology, Physiology, Genetics and Culture. Elsevier, pp. 383-424

Widdows, J., Page, D.S., 1993. Effects of tributyltin and dibutyltin on the physiological energetics of the mussel, Mytilus edulis. Mar. Environ. Res. 35, 233-249.
Widdows, J., Staff, F., 2006. Biological effects of contaminants: measurement of scope for growth in mussels ICES. Tech. Mar. Environ. Sci. 40, 1-30.

Yin-Jjuan, Z., Wei, W., Rong-Peng, L., Sheng, Y., Yi-Jun, D., Jiang, Y., 2008. Biological characteristics of a highly-active marine-derived Bacillus thuringiensis strain. J. Microbiol. 28, 43-46.

Zhen, Y., Aili, J., Changhai, W., 2010. Oxygen consumption, ammonia excretion, and filtration rate of the marine bivalve Mytilus edulis exposed to methamidophos and omethoate. Mar. Freshw. Behav. Physiol. 43, 243-255. 